J. Clin. Chem. Clin. Biochem.

Vol. 25, 1987, pp. 705-709

(C) 1987 Walter de Gruyter \& Co. Berlin - New York

\title{
Incidence of Anti HIV Antibodies and Viral Antigen in Standard and Control sera
}

\author{
By U. Köller, H. Rumpold, J. Schindler, Ch. Schweiger and F. Gabl \\ Institute of Clinical Chemistry and Laboratory Medicine, University of Vienna, Austria
}

(Received March 27/August 6, 1987)

\begin{abstract}
Summary: Most material used for control and calibration in a clinical laboratory is based on pool sera of human origin, guaranteed to be HBsAg-free. Since little information is available on the potential infectivity of HIV, the causative agent of acquired immunodeficiency syndrome (AIDS), 54 control and calibration sera, in routine use, were investigated for the incidence of antibodies to HIV by means of Elisa. Sixteen test specimens $(=30 \%)$ gave positive or borderline Elisa results and were further analysed by immunoblotting, resulting in 15 samples all recognizing gp 160 and partially the p 24, p 31, p 55, p 64 and gp 120 band. Only one sample with borderline Elisa result was negative by this assay. Furthermore, all sera were examined for the presence of viral antigen by a solid phase Elisa. All samples under investigation gave negative antigen Elisa results. Bearing in mind that the sensitivity of this assay is limited to $10 \mu \mathrm{g} / \mathrm{l}$ of viral antigen, no conclusion on infectivity should be drawn. The high incidence of HIV-antibodies in the sera investigated demands that this material should be handled with special care by laboratory personnel.
\end{abstract}

\section{Introduction}

The acquired immunodeficiency syndrome (AIDS) (1) is a rather recently described disease primarily affecting certain risk groups like promiscuous homosexuals, drug addicts and haemophiliacs who have received clotting concentrates, which have not been tested for HIV-antibodies or inactivated by heat, and the sexual partners of these groups $(2-4)$. The causative agent has been described as a human retrovirus designated Human $\mathrm{T}$ lymphotropic virus type III/lymphadenopathy associated virus (ḦTLV III/ LAV) $(5,6)$; in the new nomenclature it is called human immunodeficiency virus (HIV). All available evidence suggests that transmission of the virus occurs predominantly through contact with blood as well as blood derivates. However, the virus has also been isolated from other body fluids like urine or saliva of infected persons (7).

Health workers and laboratory staff are caring for an increasing number of patients, infected with HIV, and there is concern regarding their risk of infection from casual or percutaneous occasional exposure to the virus $(8,9)$. In spite of a low transmission rate of HIV infection documented within this group of persons $(10,11)$, the continuation of precautions regarding the handling of body fluids is recommended and emphasized. Therefore in Austria all specimens for laboratory investigations that are suspected to come from HIV-positive individuals have to be marked yellow/red, for handling with special care by laboratory staff.

For control and calibration purposes materials from human sources are generally preferred, in order to maintain the same matrix as the test specimen of interest. For this purpose most vendors provide preparations tested for $\mathrm{HBsAg}$, to minimize the potential risk of hepatitis B infection. Only partial information is available on the incidence of antibodies to HIV in quality assurance sera routinely used in laboratories and their potential risk of HIV transmission. Therefore all control and calibration sera used in this laboratory were investigated for antibodies to HIV 
by an enzyme linked immunosorbent assay (Elisa). Since testing for anti HIV antibodies by Elisa may give false positives, screening results have to be confirmed by immunoblot analysis. Because reactivity in these assays indicates antibody presence, but not viral infectivity, all sera were tested for the evidence of viral particles using an HIV antigen Elisa.

\section{Materials and Methods}

Quality assurance reagents

A total of 54 quality assurance reagents were obtained from the following companies:

- Abbott Laboratories, North Chicago, USA ( $n=15$ ),

- American Monitor Corp. Indianapolis, USA ( $n=4)$,

- Beckman Instruments Inc., Brea, LA, USA ( $=5)$,

- Behringwerke, Marburg, FRG $(n=5)$,

- BIO RAD Laboratories, Richmond, LA, USA (n=3),

- Boehringer Mannheim Diagnostics Inc., Mannheim, FRG $(\mathrm{n}=11)$,

- Du Pont de Nemours Inc., Wilmington, USA (n = 5),

- Helena Laboratories, Beaumont, Texas, USA $(n=1)$,

- Hoffmann La Roche, Basel, Switzerland $(n=1)$,

- Immuno A'G, Vienna, Austria $(n=2)$,

- Merck, Darmstadt, FRG $(n=2)$,

- Merz + Dade, Düdingen, Switzerland $(\mathbf{n}=2)$.

\section{Elisa screening for anti HIV antibodies}

All control sera and calibrators listed above were investigated by use of a Du Pont HIV Elisa kit (Du Pont). The assay was performed according to the manufacturers instructions. 0 Phenylene-diamine was used as the chromogenic substrate, and absorbance (A) was read at $410 \mathrm{~nm}$ using a Dynatec Elisa reader within two hours after stopping the peroxidase reaction. All samples were tested in duplicate.

The cut off for reactivity was that recommended by the manufacturer, calculated as the mean absorbance of the positive controls divided by two (experiment 1: $0.680 \mathrm{~A}$, experiment
2: $0.445 \mathrm{~A}$ ), all values above were considered to be positive. Following the recommendations of the Paul Ehrlich Institute (Frankfurt, FRG), this range was extended, and all samples with absorbance values down to $50 \%$ beneath the suggested cut off (exp. 1: $0.340 \mathrm{~A}$, exp. 2: $0.223 \mathrm{~A}$ ) were also examined by the immunoblot technique.

Immunoblot analysis

$\therefore$

All positive or borderline positive Elisa results were further investigated using an enzyme linked immuno electrotransfer western blot kit (Du Pont). Briefly, transblotted nitrocellulose strips were incubated overnight with the test samples diluted 1:100. Detection of anti HIV antibodies was performed with biotinylated anti human IgG $\mathrm{H}+\mathrm{L}$ antibodies, followed by a further incubation step with an avidin-peroxidase conjugate. 2Chloro-1-naphthol was used as the chromogen, giving a purpleblue reaction product.

\section{Detection of HIV viral antigen}

For the demonstration of HIV viral antigen, a sandwich solid phase enzyme immuno assay (Abbott) was performed, following the manufacturers instructions. The chromogenic substrate for the peroxidase reaction was $o$-phenylene-diamine. The cut off for reactivity was calculated by adding 0.050 to the mean absorbance value of the three negative controls as recommended by the manufacturer. All samples were tested in duplicate and absorbance values equal to or greater than the calculated cut off value were considered reactive for HIV antigen.

\section{Results}

In this study a total fo 54 control sera and calibrators was tested for anti HIV antibody by means of Elisa. Sixteen sera $(=30 \%)$ gave positive or borderline positive Elisa results (experiment 1, cut off $0.680 \mathrm{~A}$, extended range $0.340 \mathrm{~A}$, experiment 2 , cut off $0.445 \mathrm{~A}$, extended range $0.222 \mathrm{~A}$ ). Thirty eight sera

Tab. 1. Quality assurance sera with positive Elisa results by Du Pont HIV Elisa.

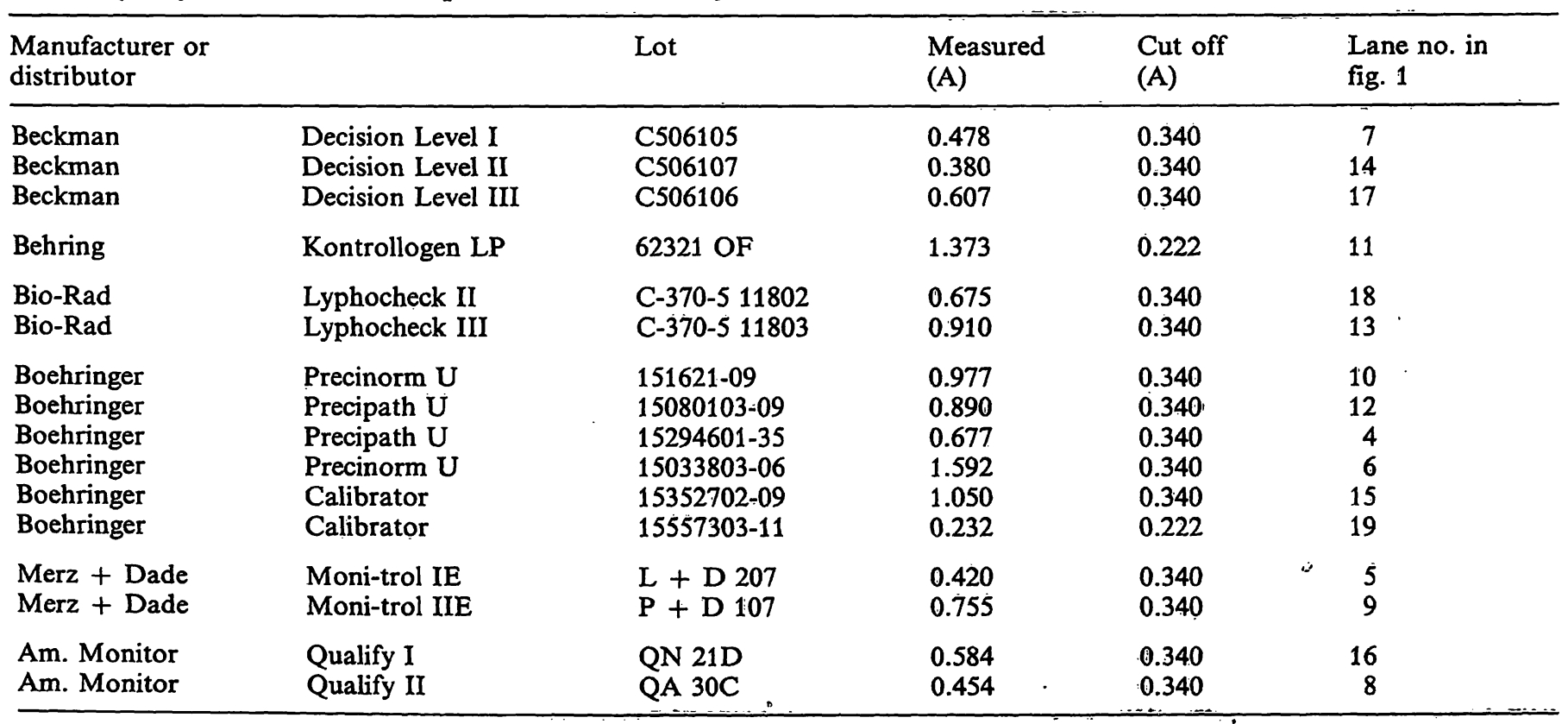


$(=70 \%)$ were considered nonreactive. Two of the 38 Elisa negative samples were equine-based but supplemented with human material. Absorbance values for positive reactive samples are shown in table 1 , for nonreactive samples in table 2.

All these 16 positive or borderline positive Elisa results were further analysed by immunoblot. The results are demonstrated in figure 1 . Lane 1 shows a negative control, lanes 2 and 20 positive controls, and lane 3 a weak reactive control sample. Lanes 4 to 19 show the 15 samples found to be Elisa-positive. The sera that were reactive in immunoblotting experiments can be identified in table 1 according to their lane number indicated in figure 1. Only one sample giving a borderline Elisa result $(0.232 \mathrm{~A}$, cut off $0.222 \mathrm{~A}$ ) was negative by immunoblot analysis (lane 19). All positive samples reacted strongly with the gp 160 band. Furthermore a weaker reactivity with $\mathrm{p} 24$, p 55 and p 64 was observed. A considerable number of samples showed an additional $\mathrm{p} 31$ band (lanes $4-6,9,10,12,13,14,15)$. All control sera and calibrators initially tested were further investigated for HIV viral antigen using the Abbott enzyme immuno assay, giving negative results for all test specimen. To investigate the sensitivity of this assay, viral antigen (Du Pont) was titrated from concentrations of $20 \mu \mathrm{g} / 1$ down to $5 \mu \mathrm{g} / \mathrm{l}$. The lowest detectable concentration of viral antigen by this assay was 10 $\mu \mathrm{g} / 1$ (see fig. 2).

Tab. 2. Quality assurance sera with negative Elisa results.

\begin{tabular}{|c|c|c|c|c|}
\hline $\begin{array}{l}\text { Manufacturer or } \\
\text { distributor }\end{array}$ & & Lot & $\begin{array}{l}\text { Measured } \\
\text { (A) }\end{array}$ & $\begin{array}{l}\text { Cut off } \\
\text { (A) }\end{array}$ \\
\hline $\begin{array}{l}\text { Abbott } \\
\text { Abbott } \\
\text { Abbott } \\
\text { Abbott } \\
\text { Abbott } \\
\text { Abbott } \\
\text { Abbott } \\
\text { Abbott } \\
\text { Abbott } \\
\text { Abbott } \\
\text { Abbott } \\
\text { Abbott } \\
\text { Abbott } \\
\text { Abbott } \\
\text { Abbott }\end{array}$ & $\begin{array}{l}\text { Phenytoin H } \\
\text { Phenytoin M } \\
\text { Phenytoin L } \\
\text { Phenobarbital H } \\
\text { Phenobarbital M } \\
\text { Phenobarbital L } \\
\text { Digitoxin H } \\
\text { Digitoxin M } \\
\text { Digitoxin L } \\
\text { Digoxin H } \\
\text { Digoxin M } \\
\text { Digoxin L } \\
\text { Methotrexate H } \\
\text { Methotrexate M } \\
\text { Methotrexate L }\end{array}$ & $\begin{array}{l}9507-10 \quad 83-107 \mathrm{AZ} \\
9507-10 \quad 83-107 \mathrm{AZ} \\
9507-10 \quad 83-107 \mathrm{AZ} \\
9500-10 \quad 90-288 \mathrm{AZ} \\
9500-10 \quad 90-288 \mathrm{AZ} \\
9500-10 \quad 90-288 \mathrm{AZ} \\
9535-1086-659 \mathrm{AZ} \\
9535-1086-659 \mathrm{AZ} \\
9535-1086-659 \mathrm{AZ} \\
9511-1087-353 \mathrm{AZ} \\
9511-1087-353 \mathrm{AZ} \\
9511-1087-353 \mathrm{AZ} \\
9522-1088-091 \mathrm{SV} \\
9522-1088-091 \mathrm{SV} \\
9522-10 \quad 88-091 \mathrm{SV}\end{array}$ & $\begin{array}{l}0.103 \\
0.084 \\
0.072 \\
0.065 \\
0.060 \\
0.064 \\
0.064 \\
0.070 \\
0.070 \\
0.075 \\
0.074 \\
0.074 \\
0.067 \\
0.064 \\
0.080\end{array}$ & $\begin{array}{l}0.340 \\
0.340 \\
0.340 \\
0.340 \\
0.340 \\
0.340 \\
0.340 \\
0.340 \\
0.340 \\
0.340 \\
0.340 \\
0.340 \\
0.340 \\
0.340 \\
0.340\end{array}$ \\
\hline $\begin{array}{l}\text { Am. Monitor } \\
\text { Am. Monitor }\end{array}$ & $\begin{array}{l}\text { Standard } 1 \\
\text { Standard } 2\end{array}$ & $\begin{array}{l}\text { SL } 1022 \text { C } \\
\text { SH } 1033 \text { B }\end{array}$ & $\begin{array}{l}0.004 \\
0.005\end{array}$ & $\begin{array}{l}0.340 \\
0.340\end{array}$ \\
\hline $\begin{array}{l}\text { Behring } \\
\text { Behring } \\
\text { Behring } \\
\text { Behring }\end{array}$ & $\begin{array}{l}\text { NT Protein Kontr. } \\
\text { Pathoplasma I } \\
\text { Pathoplasma II } \\
\text { Kontrollplasma N }\end{array}$ & $\begin{array}{l}065118 \\
502848 \mathrm{~A} \\
502942 \mathrm{~A} \\
502788 \mathrm{C}\end{array}$ & $\begin{array}{l}0.065 \\
0.050 \\
0.055 \\
0.056\end{array}$ & $\begin{array}{l}0.340 \\
0.340 \\
0.340 \\
0.340\end{array}$ \\
\hline Bio-Rad & Lyphocheck I & C $370-511801$ & 0.170 & 0.340 \\
\hline $\begin{array}{l}\text { Boehringer } \\
\text { Boehringer } \\
\text { Boehringer } \\
\text { Boehringer } \\
\text { Boehringer }\end{array}$ & $\begin{array}{l}\text { Plasmacontr. Plus } \\
\text { Precinorm I } \\
\text { Preciclot I } \\
\text { Preciclot II } \\
\text { Precichrom II }\end{array}$ & $\begin{array}{l}175927 / 5269 \\
152287 \\
615382 \\
615382 \\
152419\end{array}$ & $\begin{array}{l}0.050 \\
0.010 \\
0.012 \\
0.005 \\
0.006\end{array}$ & $\begin{array}{l}0.340 \\
0.222 \\
0.222 \\
0.222 \\
0.222\end{array}$ \\
\hline $\begin{array}{l}\text { Du Pont } \\
\text { Du Pont } \\
\text { Du Pont } . . \\
\text { Du Pont } \\
\text { Du Pont }\end{array}$ & $\begin{array}{l}\text { Bilirubin Calibr. } 1 \\
\text { Bilirubin Calibr. } 2 \\
\text { Bilirubin Calibr. } 3 \\
\text { ACA Normal } \\
\text { ACA Elevated }\end{array}$ & $\begin{array}{l}011251 \mathrm{~A} \\
011251 \mathrm{~B} \\
011251 \mathrm{C} \\
6 \mathrm{DB} 621 \\
6 \mathrm{DB} 626\end{array}$ & $\begin{array}{l}0.002 \\
0.003 \\
0.003 \\
0.002 \\
0.003\end{array}$ & $\begin{array}{l}0.222 \\
0.222 \\
0.222 \\
0.222 \\
0.222\end{array}$ \\
\hline Helena Lab. & CK/LC Isoencyme Ko & 5131 & 0.012 & 0.340 \\
\hline Roche & Control Serum P & B06379705 & 0.004 & 0.340 \\
\hline $\begin{array}{l}\text { Immuno } \\
\text { Immuno }\end{array}$ & $\begin{array}{l}\text { Konroll Pl. AK-D } \\
\text { Kontroll Pl. AK-R }\end{array}$ & $\begin{array}{l}\text { AK } 082 \\
\text { AK } 080\end{array}$ & $\begin{array}{l}0.025 \\
0.020\end{array}$ & $\begin{array}{l}0.222 \\
0.222\end{array}$ \\
\hline $\begin{array}{l}\text { Merck } \\
\text { Merck }\end{array}$ & $\begin{array}{l}\text { Seronorm TM } \\
\text { Pathonorm L }\end{array}$ & $\begin{array}{l}211025 / 74 \\
212123 / 20\end{array}$ & $\begin{array}{l}0.004 \\
0.003\end{array}$ & $\begin{array}{l}0.222 \\
0.222\end{array}$ \\
\hline
\end{tabular}




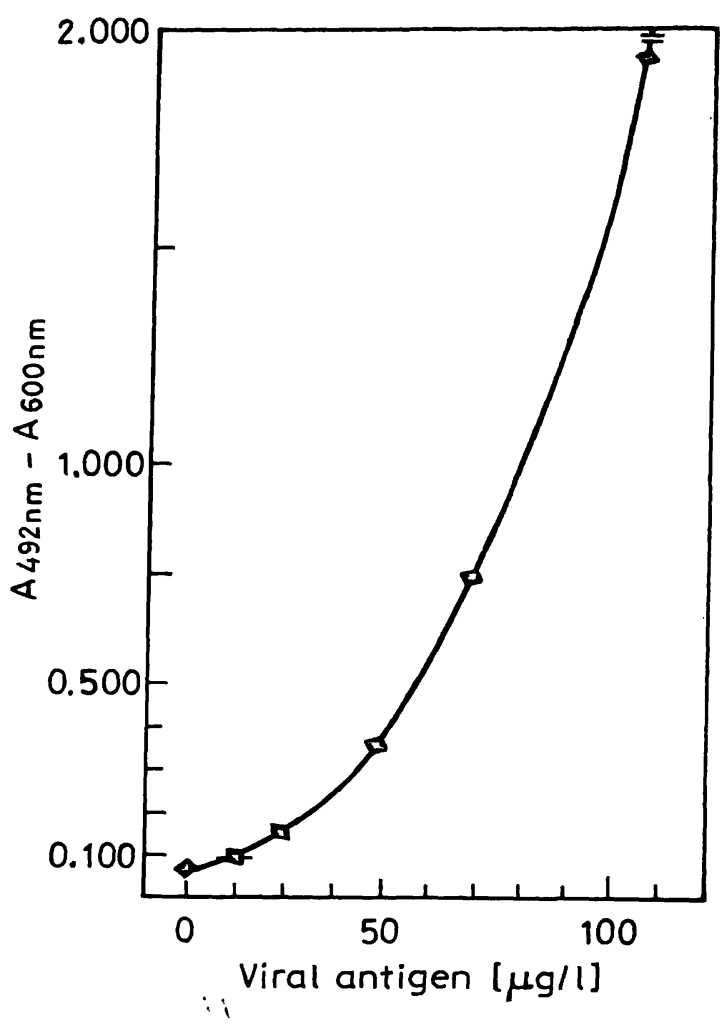

Fig. 1. Immunoblot reactivity of control and calibration sera tested in HIV antibody Elisa:

lane 1: negative control,

lanes 2, 20: positive control,

lane 3: weak positive control,

lanes 4-19: samples tested;

Individual samples may be identified in tab. 1.

\section{Discussion}

For quality assurance sera originating from human material, the number of donors may be 6000 or more. Although pools are tested for $\mathrm{HBsAg}$, donors are often members of risk groups for HIV infection. Therefore 54 control sera and calibrators routinely used in this laboratory were tested for antibodies to HIV. Elisa screening gave about $30 \%$ reactive samples. These data are in agreement with Howanitz et al. (12), who reported the presence of HIV antibodies in about $31 \%$ of quality assurance sera on the basis of initial tests. However, 7 of 45 reactive samples in this study were nonreactive on repeated testing. In our study, 15 of the 16 positive or borderline Elisa results were confirmed by immunoblot analysis, indicating that the observed Elisa reactivity was not due to preparation artefacts. The one sample giving a negative immunoblot result had also shown absorbance values close to the extended cut off value. The fact that gp 41 could only be found in two of the 15 positively reactive sera investigated may be due to the dilution effect, since all these quality assurance materials are produced from pool sera, and this band is weaker than the others even in strongly positive cases. However, gp 160, which is known to be the .

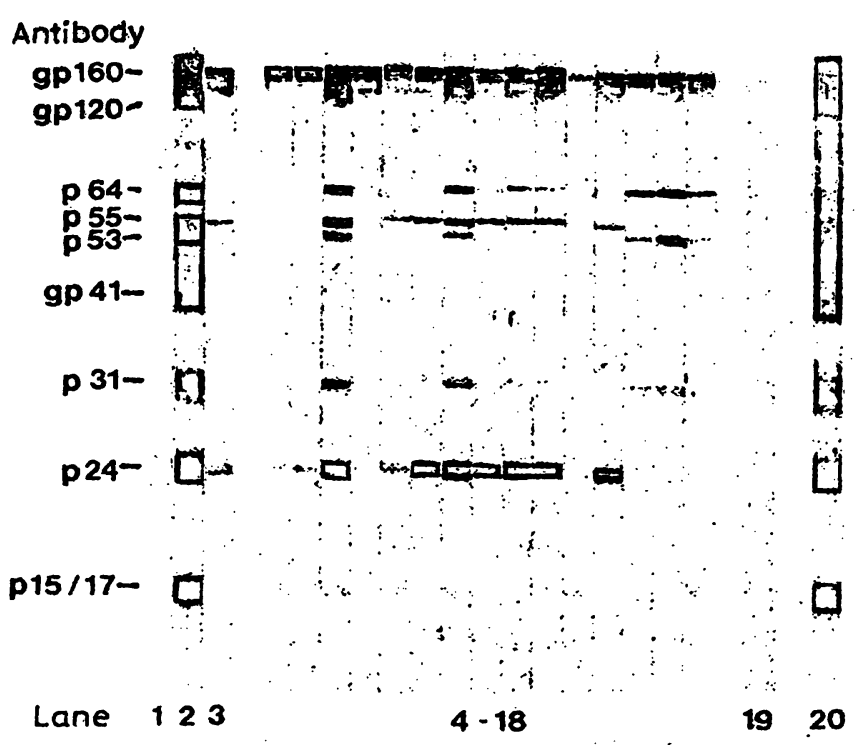

Fig. 2. Titration of viral antigen: cut off for sensitivity of the assay is $10 \mu \mathrm{g} / 1$ viral antigen. Absorbance without viral antigen 0.057 .

viral protein to which the highest titers of antibodies are mounted, gave the strongest reactivity in all samples. Moreover, all 54 samples were tested for viral antigen, but no positivity was observed. However, titration of viral antigen using this Elisa procedure showed sensitivity down to concentrations of $10 \mu \mathrm{g}$ antigen per I diluent only. Therefore no conclusions can be drawn regarding the infectivity of the samples tested, because the amount of infectious agent may be beneath the quantities detectable by the antigen Elisa.

In high percentages of haemophiliacs receiving commercial clotting concentrates which have not been tested for anti-HIV antibodies and heat inactivated, transmission of the virus has been described, resulting in the development of antibodies to HIV and exacerbation of AIDS $(13,14,15)$. HIV has been isolated from peripheral blood and other body fluids of most patients with pre-AIDS, and from a considerable number of patients with the fully developed picture of AIDS. The virus has been isolated from lyophilized factor VIIII concentrates (16), indicating that the virus is resistant to the lyophilization procedure.

These reșults strengthen the case for handling all control sera with special care, and according to the safety precautions against hepatitis $B$ infection, which will also protect against HIV infection (17). Since methods are now available for testing sera for the presence of anti HIV antibodies, and, furthermore, rather mild procedures for inactivating the virus have been established (18), vendors should be obliged to provide control and calibration materials which are anti HIV antibody-negative, in order to lower the potential risk for laboratory personnel.

$$
\text { i: }
$$

J. Clin. Chem. Clin. Biochem. / Vol. 25, 1987 / No. 10 


\section{References}

1. Curran, J. W. (1983) New Engl. J. Med. 309, 609-610.

2. Gottlieb, M. S., Schroff, R., Schanker, H. M., Weisman, J. D., Thiem Fan, P., Wolf, R. A. \& Saxon, A. (1981) New Engl. J. Med. 305, 1425.

3. Masur, H., Michelis, M. A., Greene, J. B., Onorato, I., Van Stouwe, R. A., Holzman, R. S., Wormser, G., Brettmann, L., Lange, M., Murray, J. W. \& WuninghamRundles, S. (1981) N. Engl. J. Med. 305, $1431-17435$.

4. Davis, K. G., Horsburgh, C. R., Hasiba, U., Scholket, A. L. \& Kirckpatrick, C. H. (1985) Ann. Int. Med. 98, 284286.

5. Popovic, M., Sarngadharan, M. G., Read, E. \& Gallo, R. C. (1984) Science 224, 497-500.

6. Barre-Sinoussi, F., Chermann, J. C., Rey, F., Nugeyre, M. T., Chamaret, S., Gruest, J., Dauguet, C., Axler Blin., Verzinet-Brun, F., Rouzioux, C., Rosenbaum, W. \& Montagnier, L. (1983) Science 220, 868-871.

7. Goedert, J. J., Blattner, W. A. (1985) The epidemiology of AIDS and related conditions, in: AIDS: Ethiology diagnosis, treatment and prevention (De Vita, V. T., Hellmann, S. \& Rosenberg, S. A., eds.) Philadelphia J. B. Lippincott Co, pp. 1-30.

8. Centers for disease control (1982) Morbid. Mortal. Weekly Rep. 31, 577-580.

9. Centers for disease control (1983) Morbid. Mortal. Weekly Rep. 32, 450-451.
10. Hirsch, M., Wormser, G. P. \& Schooley, R. T. (1985) N. Engl. J. Med. 313, 1-4.

11. Weiss, S. H., Saxinger, W. C., Rechtman, D., Grieco, M H., Nadler, J., Holman, S., Grinzburg, H. M., Groopman, J. E., Goedert, J. J., Markham, P. D., Gallo, R. C. \& Blattner, A. W. (1985) J. Amer. Med. Ass. 254, 20892093.

12. Howanitz, P. J., McBride, J. H., Kliewer, K. E. \& Rodgerson, D. O. (1986) Clin. Chem. 32, 773-777.

13. Evatt, B. L., Ramsey, R. B., Lawrence, D. N., Zila, L. D. \& Curran, J. W. (1984) Ann. Intern. Med. 100, 499504.

14. Ledermann, M. M., Ratnoff, O. D., Evatt, B. L. \& Mc Dougal, J. S. (1985) Ann. Intern. Med. 102, 753-757.

15. Smolen, J. S., Bettelheim, P., Köller, U., Mc Dougal, S., Graininger, W., Luger, T. A., Knapp, W. \& Lechner, K. (1985) J. Clin. Invest. 75, 1828-1833.

16. Levy, J. A., Mitra, G. \& Mozen, M. M. (1984) Lancet II, $722-723$.

17. Bericht der Kommission für Fragen der Virusdesinfektion in der Humanmedizin der Deutschen Vereinigung zur Bekämpfung der Viruskrankheiten (DVV) and des Bundesgesundheitsamtes (BGA) (1987) Deutsches Ärzteblatt 84/ 18, 1217-1226.

18. Heinburger, N., Schwinn, H., Gratz, P., Luben, G., Kumpe, G. \& Herchenhan, B. (1981) Drug. Res. 31, 619-622.

Prof. Dr. F. Gabl

Institut für Klinische Chemie

und Laboratoriumsdiagnostik

der Universität Wien

Lazarettgasse 14

A-1090 Wien 
